\title{
Late Miocene remains from Venta del Moro (Iberian Peninsula) provide further insights on the dispersal of crocodiles across the late Miocene Tethys
}

\author{
Massimo Delfino, ${ }^{1,2 *}$ (1) Àngel H. Luján, ${ }^{2,3}$ Juan Abella, ${ }^{2,4 *}$ (1) David M. Alba, ${ }^{2}$ Madelaine Böhme, ${ }^{5,6}$ \\ Alejandro Pérez-Ramos, ${ }^{7}$ Emanuel Tschopp, ${ }^{1,8}$ Jorge Morales, ${ }^{9}$ and Plini Montoya ${ }^{10}$ \\ ${ }^{1}$ Dipartimento di Scienze della Terra, Università degli Studi di Torino, Via Valperga Caluso, 35, 10125 Torino, Italy <massimo.delfino@ \\ unito.it> \\ ${ }^{2}$ Institut Català de Paleontologia Miquel Crusafont, Universitat Autònoma de Barcelona, Edifici ICTA-ICP, c/ Columnes s/n, Campus de la \\ UAB, 08193 Cerdanyola del Vallès, Barcelona, Spain <angel.lujan@icp.cat>, <juan.abella@icp.cat>, <david.alba@icp.cat> \\ ${ }^{3}$ Department of Geological Sciences, Faculty of Sciences, Masaryk University, Kotlárská 267/2, 61137 Brno, Czech Republic \\ ${ }^{4}$ Instituto Nacional de Biodiversidad, Pje. Rumipamba N. 341 y Av. de los Shyris (Parque La Carolina), Quito, Ecuador \\ ${ }^{5}$ Department of Geosciences, Eberhard-Karls-Universität Tübingen, Sigwartstrasse 10, D-72076 Tübingen, Germany <m.boehme@ifg.uni- \\ tuebingen.de> \\ ${ }^{6}$ Senckenberg Centre for Human Evolution and Palaeoenvironment, Sigwartstrasse 10, D-72076 Tübingen, Germany \\ ${ }^{7}$ Departamento de Ecología y Geología, Facultad de Ciencias, Universidad de Málaga, 29071, Málaga, Spain <pera@ uma.es> \\ ${ }^{8}$ American Museum of Natural History, Division of Paleontology, Central Park West at 79th Street, New York, NY 10024, USA <etschopp@ \\ amnh.org> \\ ${ }^{9}$ Museo Nacional de Ciencias Naturales (MNCN-CSIC), José Gutiérrez Abascal 2, 28006 Madrid, Spain <mcnm166@mncn.csic.es> \\ ${ }^{10}$ Departament de Botànica i Geologia, Universitat de València, Doctor Moliner 50, 46100 Burjassot, València, Spain <plinio.montoya@uv.es>
}

\begin{abstract}
The dispersal of Crocodylus from Africa to Europe during the Miocene is not well understood. A small collection of cranial fragments and postcranial elements from the latest Miocene (6.2 Ma) site of Venta del Moro (Valencia, Spain) have previously been referred to Crocodylus cf. C. checchiai Maccagno, 1947 without accompanying descriptions. Here we describe and figure for the first time the crocodylian remains from Venta del Moro, which represent at least two individuals. Our comparisons indicate that this material clearly does not belong to Diplocynodon or Tomistoma - the only two other crocodylians described so far for the European late Miocene. The material is only tentatively referred to cf. Crocodylus sp. because the apomorphies of this genus are not preserved and a referral to C. checchiai cannot be supported on a morphological basis. However, it is likely that this late Miocene species, originally described from Libya (As Sahabi) and later identified also in Kenya, could have dispersed across the Mediterranean Basin multiple times and colonized the southern areas of Mediterranean Europe, as evidenced by several Crocodylus or Crocodylus-like remains described during the past years.
\end{abstract}

\section{Introduction}

In the past few years, the knowledge of the geologically youngest and therefore last European crocodylians has improved significantly thanks to the revision of historical collections and the discovery of new remains. On the basis of diagnostic and easily identifiable remains (i.e., skulls, lower jaws, ilia, osteoderms), three genera are recorded: the long-snouted Tomistoma Müller, 1846 (or Gavialosuchus Toula and Kail, 1885), the short-snouted Diplocynodon Pomel, 1847, and Crocodylus Laurenti, 1768. Tomistomine crocodylians had been present in Europe since the Eocene, and their last local representatives come from marginal marine deposits of the late Miocene (Piras et al., 2007; Zoboli et al., 2019). The endemic alligatoroid Diplocynodon had inhabited Europe since the late Paleocene and went extinct in the middle Miocene (Böhme, 2003; Martin

*Corresponding authors. et al., 2014; Díaz Aráez et al., 2017; Luján et al., 2019). Interestingly, in the late Miocene the crocodylid Crocodylus appeared in the central Mediterranean sector of southern Europe, where it lingered at least until the Messinian or even the Zanclean (Delfino et al., 2007; Delfino and Rook, 2008; Delfino and Rossi, 2013; Piñero et al., 2017, supplementary data). Ironically, the identification of Crocodylus in the European fossil record overturned the widely accepted opinion that the latter taxon never inhabited Europe, despite the fact that the name Crocodylus (or Crocodilus) was widely used in the nineteenth century for different European species that, once revised, turned out to belong to different genera (Brochu, 2000). Among others, worth mentioning are the cases of Crocodilus affuvelensis Matheron, 1869 from the Cretaceous of France, referred by Martin and Buffetaut (2008) to the genus Massaliasuchus Martin and Buffetaut, 2008; Crocodilus arduini De Zigno, 1880 from the Eocene of Italy, now referred to Megadontosuchus Mook, 1955 (Piras et al., 2007); Crocodylus depressifrons Blainville, 1855 from the Paleocene-Eocene of France, now referred to 
Asiatosuchus Mook, 1940 (even if it clearly does not belong to Crocodylus, there are still questions on its generic attribution; see Delfino and Smith, 2009; Delfino et al., 2019); and Crocodylus spenceri Buckland, 1836 from the Eocene of Great Britain, now referred to Kentisuchus Mook, 1940 (Brochu, 2007).

The first published evidence for the presence of Crocodylus in Europe consists of few cranial and postcranial remains coming from the latest Miocene-earliest Pliocene (MessinianZanclean) fissure fillings of the Gargano promontory in Southern Italy. The presence of undetermined crocodylian remains had already been reported since the paper by Freudenthal (1971) on the vertebrates from the area, but only a revision of the material housed in the collections of the Dipartimento di Scienze della Terra dell'Università degli Studi in Firenze (Italy), of the Naturalis Biodiversity Centre in Leiden (the Netherlands), and of the Universitätsinstitut und Staatssammlung für Paläontologie und historische Geologie in Munich (Germany) led to the identification of Crocodylus on the basis of phylogenetically relevant characters (Delfino et al., 2007).

The following revision (Delfino and Rook, 2008) of the historical material from the late Miocene (Turolian) lignites of Southern Tuscany (Italy) initially described as Crocodylus bambolii Ristori, 1890, allowed tracking down all the original remains studied by Ristori (1890). Crocodylian remains from this area (Casteani, Montebamboli, and Ribolla) are housed in three Italian collections: Museo di Storia Naturale dell'Accademia dei Fisiocritici di Siena; Museo di Storia Naturale, Sezione di Geologia e Paleontologia, dell'Università di Firenze; and Museo Geologico Giovanni Capellini in Bologna. Although this abundant material includes partial skulls, fragmentary lower jaws, and postcranial remains, the validity of the species C. bambolii could not be confirmed due to poor preservation, and the type material was therefore referred to cf. Crocodylus sp.

The third, and so far last, ascertained possible evidence of the presence of Crocodylus in Europe comes from the late Miocene (Tortonian) sandstones of Scontrone in Central Italy

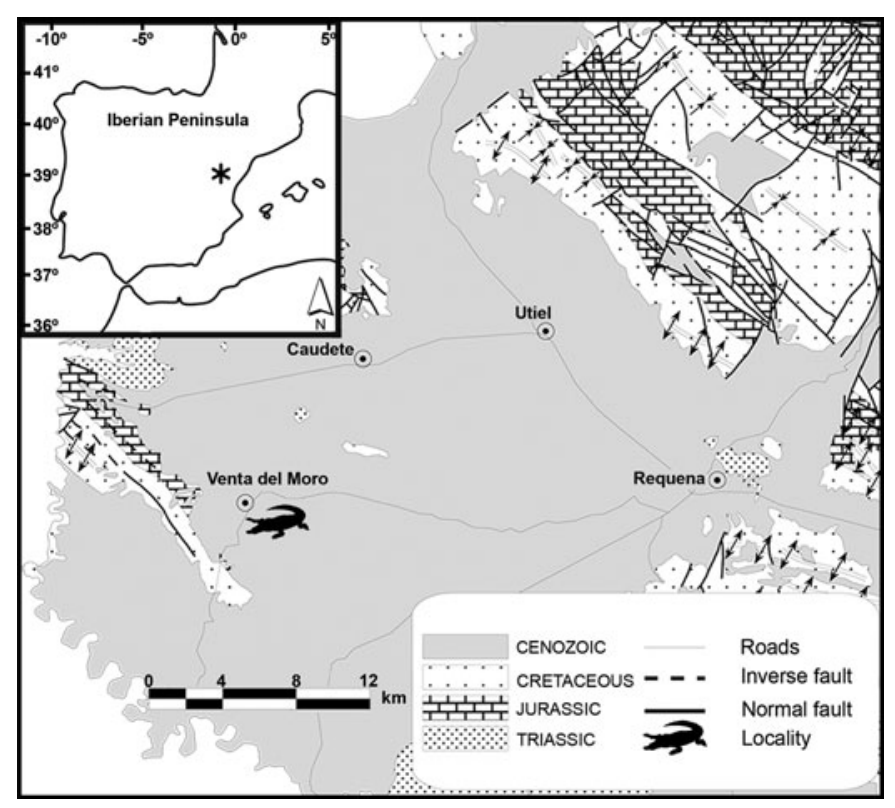

Figure 1. Map of the Iberian Peninsula showing the position of Venta del Moro. (material housed in the collections of the Soprintendenza per i Beni Archeologici dell'Abruzzo, Chieti, Italy). The referral to Crocodylus sp. of the first teeth discovered in this locality (Rustioni et al., 1992) was questioned by Kotsakis et al. (2004) and Delfino et al. (2007), but the subsequent discovery of a lower jaw (along with few other fragmentary, noninformative skeletal elements) confirmed that the crocodylian from Scontrone likely belongs to the genus Crocodylus (cf. Crocodylus sp.; Delfino and Rossi, 2013). Worth mentioning is that the latter remains represent the geologically oldest evidence of Crocodylus, being dated to at least 9 Ma (see Delfino and Rossi, 2013 and references therein), whereas the oldest remains from Africa date back to about $7 \mathrm{Ma}$ (Brochu and Storrs, 2012). Because Europe cannot be considered the center of origin of Crocodylus, it is therefore likely that the first evolutionary steps of this genus were not recorded or are still to be discovered either in Africa or in Asia (Meredith et al., 2011; Oaks, 2011; Brochu and Storrs, 2012; Nicolaï and Matzke, 2019).

Other European late Miocene-early Pliocene localities yielded remains of crocodylians: Alhaurín el Grande-1 (GuerraMerchán et al., 2013); Brisighella (Delfino, 2002); Castro (Alfaro et al., 1995); Crevillente 2 and 15 (Montoya, 1994; Montoya and Alberdi, 1995); Crevillente 4 (Böhme and Ilg, 2003); Fiume Santo (Abbazzi et al., 2008) and other Sardinian localities (Zoboli et al., 2019); Masía de la Roma 4B (Böhme and Ilg, 2003); Moncucco Torinese (Colombero et al., 2017); Plakias (Georgalis et al., 2016); Puerto de la Cadena (Piñero et al., 2017); and Ribatejo (Böhme and Ilg, 2003). However, so far it has not been possible to ascertain or discard the presence of Crocodylus because the materials consist nearly exclusively of very fragmentary remains (in many cases just isolated teeth sometimes referred to Diplocynodon or Tomistoma) that are not diagnostic at genus rank and should be considered as indeterminate crocodylians (Brochu, 2000).

The only other possible evidence for the presence of Crocodylus in Europe comes from the late Miocene of Venta del Moro (VM) in Valencia, Spain, where Crocodylus cf. C. checchiai Maccagno, 1947 was preliminarily reported by Montoya et al. (2006). Here we describe for the first time the crocodylian material from this locality, and besides reconsidering its identification, we discuss its relevance in the context of the dispersal of Crocodylus across the late Miocene Tethys.

\section{Geological setting}

The locality of VM was first reported by Aguirre et al. (1973). Located $2 \mathrm{~km}$ southeast of the village with the same name (UTM Zone 30S, 642494E, 4370967N), in the Cabriel Basin (Valencia, Spain; Fig. 1), it has yielded an abundant and diverse fossil assemblage of plants (pollen and macroflora; CasasGallego et al., 2015) and animals (both invertebrates and vertebrates; Montoya et al., 2006, 2009). The faunal list includes 48 species of mammals, of which nine have VM as their type locality. VM also records the first appearance datum (FAD) in Europe for the ursoid Agriotherium (Morales, 1984; Abella et al., 2014, 2019), the camel Paracamelus (Morales et al., 1980; Morales, 1984; Pickford et al., 1993, 1995; van der Made and Morales, 1999), and the murid Paraethomys (Gibert et al., 2013; Mansino et al., 2017). For additional information on the faunal 
assemblage from VM see Morales (1984), Montoya et al. (2006, 2009, 2011), Pesquero et al. (2007), Salesa et al. (2010), Alba et al. (2015), Mansino et al. (2014, 2015a, 2017, 2018), and Crespo et al. (2018).

Magnetostratigraphic correlation of VM with chron C3An indicates an estimated age of 6.23 Ma (Gibert et al., 2013), while the mammal assemblage implies a correlation with MN13 (Mein, 1990, 1999; De Bruijn et al., 1992) and, more precisely, the Teruel local biozone M3 (van Dam et al., 2006) within the late Turolian or Ventian mammal age (Morales et al., 2013). This time span is characterized by important dispersal events of multiple mammalian taxa into western Europe (Pickford and Morales, 1994; Agustí et al., 2006; van der Made et al., 2006; Minwer-Bararat et al., 2009; Gibert et al., 2013; Mansino et al., 2015b; García-Alix et al., 2016; Minwer-Barakat et al., 2018), mainly from Asia (camels, canids, colobines, ursoids), but also from Africa (hippos, crocodiles). VM also records other taxa of African affinities, such as the murid rodent Paraethomis meini Michaux, 1969 and the chiropteran Myotis podlesicensis Crespo et al., 2018 (Mansino et al., 2017; Crespo et al., 2018).

\section{Materials and methods}

The study presented here is based on all fossil crocodylian remains found in VM (Fig. 1), which were formerly housed at the Museu de Geologia de la Universitat de València, Spain (MGUV) and are currently at the Museu de la Universitat de València d'Història Natural. Pictures of the most relevant specimens were taken using a Canon EXUS 170 digital camera. Measurements were taken with a digital caliper to the nearest $0.1 \mathrm{~mm}$.

Repository and institutional abbreviation.-Museu de Geologia de la Universitat de València, Spain (MGUV), Valencia, Spain.

\section{Systematic paleontology}

Order Crocodylia Gmelin, 1789

Family Crocodylidae Laurenti, 1768

Genus Crocodylus Laurenti, 1768

Type species.—Crocodilus vulgaris Cuvier, 1807

\section{cf. Crocodylus sp. \\ Figures 2, 3}

Description.-The only available jugal (MGUV 144699) is very fragmentary, and its only relevant character is the presence of a slender postorbital bar that is inset relative to the lateral surface of the element (it is not clear whether all the bone fragments cataloged under this collection number belong to the same skeletal element).

A well-preserved frontal (MGUV 14472; Fig. 2.1-2.4) clearly lacks any trace of a 'step' at the base of the frontal process (however, most of this process is broken off). The frontoparietal suture is deeply concave anteriorly (it is nearly V-shaped as in derived crocodylids), and the supratemporal fenestrae did not reach the frontal. The dorsal surface of the bone is markedly concave, devoid of a midsagittal crest, but ornamented with large pits (Fig. 2.1, 2.2).
The squamosal, partially preserved in MGUV 18828, has a long and relatively slender paroccipital process (Fig. 2.5-2.10). The single exoccipital available from VM (MGUV 18828; Fig. 2.5-2.8) has no trace of a paroccipital boss. The posterolateral edge of this element forms a laminar structure that overhangs the wide opening of the cranioquadrate passage. The foramen vagi is the largest of the foramina of the area, followed by a considerably smaller foramen caroticum posterius (which is placed medioventral to the first) and then by the small foramen for the cranial nerve XII (which is located close to the medial corner of the foramen vagi). The exoccipital preserves the contact surface with the basioccipital and part of the rim of the foramen magnum (Fig. 2.5-2.8).

Information on the morphology of the quadrate is available thanks to MGUV 18828, a right quadrate still sutured with the overlying exoccipital and partial squamosal (Fig. 2.5-2.10), and the isolated right quadrate MGUV 14467 (Fig. 2.11, 2.14). MGUV 18828 is smaller (mediolateral breadth of 27.2 $\mathrm{mm}$ ) and better preserved than MGUV 14467 (original mediolateral breadth $>34 \mathrm{~mm}$ ). The medial hemicondyle is preserved only in MGUV 18828, in which it is clearly expanded so that it does not significantly slope when seen in posterior view (Fig. 2.5, 2.6, 2.9, 2.10). As for the original opening of the foramen aëreum, none of the two available quadrates shows it, but both preserve a trace revealing its presence very close to the medial edge of the quadrate (Fig. 2.5, 2.6, 2.9-2.14). The medial and dorsomedial surfaces of MGUV 14467 are eroded so that the ventrolateral surface of a large canal can be seen at the medial margin of the quadrate ramus. The posterior termination of this canal originally corresponded to the foramen aëreum (Fig. 2.112.14). The medial surface of MGUV 18828 is well preserved close to the medial hemicondyle, but it is broken off in its anterior portion, so that also in this case the ventral surface of the canal corresponding to the foramen aëreum is visible close to the medial edge of the quadrate (Fig. 2.9, 2.10). The squamosal of MGUV 18828 is not completely preserved, but it seems that it did not develop a significant 'squamosal horn.'

A very small portion of a parietal is preserved in MGUV 14470 (Fig. 2.15-2.18). The dorsal surface is nearly flat and reaches the posteromedial rim of the left supratemporal fenestra, which is slightly raised (Fig. 2.15, 2.16).

The supraoccipital is part of the fragment of the skull table MGUV 14470 and is only very modestly visible in dorsal (Fig. 2.15, 2.16) and posterior (Fig. 2.17, 2.18) views. Its dorsal surface is lowered relative to that of the surrounding parietal (Fig. 2.15, 2.16). In posterior view, it has a vaguely hexagonal shape (Fig. 2.17, 2.18).

The only available ectopterygoid is so fragmentary that it bears no significant information.

The surangular MGUV 18835 and the angular MGUV 14466 clearly belong to the same individual, because they are congruent in terms of size and general shape, and the fine morphology of the preserved portion of the surangular-angular suture matches very well on both elements (Fig. 3.1, 3.4). They both belong to a rather large specimen, the length of their preserved parts being 19.0 and $18.4 \mathrm{~mm}$, respectively. The surangular terminates anteriorly with a long dorsal process overhanging a small ventral process; the posterodorsal tip seems to be complete (Fig. 3.1, 3.4). The external mandibular fenestra was 


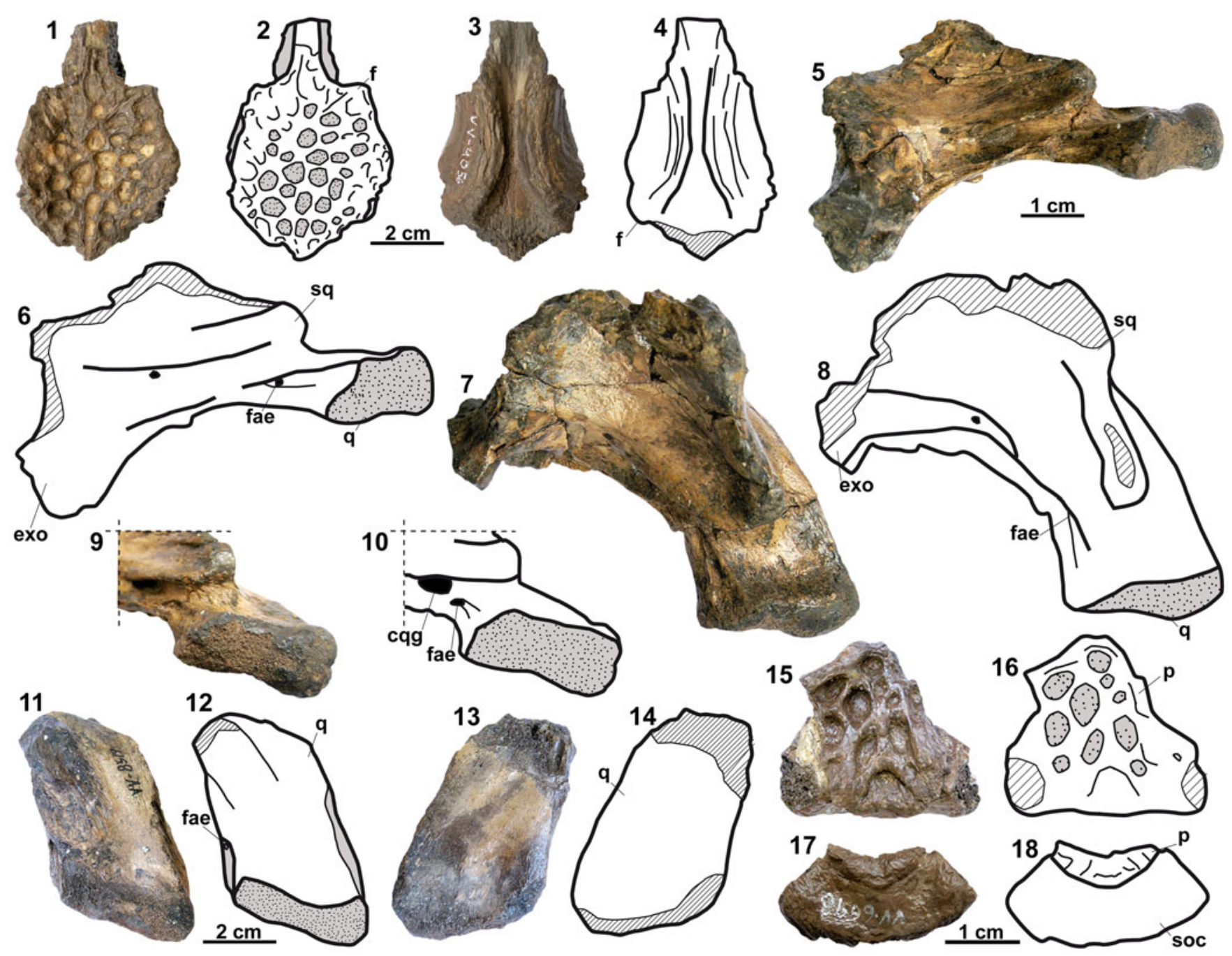

Figure 2. Photos and line drawings of crocodylian remains from the late Miocene of Venta del Moro. (1-4) Frontal (MGUV 14472): (1, 2) dorsal view; (3,4) ventral view. (5-10) Right quadrate sutured with the overlying exoccipital and partial squamosal (MGUV 18828): $(\mathbf{5 , 6})$ posterior view; $(\mathbf{7 , 8})$ dorsal view; $(\mathbf{9 , 1 0})$ detail of the quadrate condyle in posterior view. (11-14) Right partial quadrate (MGUV 14467): (11, 12) dorsal view; (13, 14) ventral view. (15-18) Fragment of skull table (MGUV 14470) with part of the parietal and the supraoccipital: $(\mathbf{1 5}, \mathbf{1 6})$ dorsal view; $(\mathbf{1 7}, \mathbf{1 8})$ posterior view. cqg $=$ cranioquadrate groove; exo $=$ exoccipital; $\mathrm{f}=$ frontal; fae = foramen aëreum; $\mathrm{p}=$ parietal; $\mathrm{q}=$ quadrate; $\mathrm{sq}=$ squamosal; $\mathrm{soc}=$ supraoccipital. Oblique lines denote missing portions or cast.

quite large, but not enough to see the foramen intermandibularis caudalis in lateral view (Fig. 3.1, 3.2). The angular-surangular suture reaches the external mandibular fenestra at its posterior angle. The lateral surface of both the surangular and the angular is ornamented with large and deep pits separated by evident ridges (Fig. 3.1, 3.2).

The partially preserved right articular MGUV 14475 (Fig. 3.13-3.16) does not show the position of the foramen aëreum because of poor preservation, but the lamina lying against the surangular is relatively well developed. The articular-surangular suture within the glenoid fossa is not linear, but bowed (Fig. 3.13-3.14). The retroarticular process is long, slender, and probably directed in a posterodorsal direction (Fig. 3.13-3.16).

Isolated teeth (Fig. 3.5-3.12) are numerous, and their sizes vary from a few millimeters (e.g., $6.5 \mathrm{~mm}$ in MGUV 25924; also very small are MGUV 14440, 16002) to $39.0 \mathrm{~mm}$ (MGUV 16006). The shape ranges from elongate, slender, and pointed as in MGUV 16002 (Fig. 3.5, 3.6), 24317, and 16001 (Fig. 3.7,
3.8) to more massive and broadly conical as in MGUV 16006, 25993, and 14504 (Fig. 3.11, 3.12) to short, proportionally massive, and apically blunt as in MGUV 14443, 16004 (Fig. 3.9, 3.10 ), and 18932. The largest tooth (MGUV 16006) only partially preserves the root (of the $39.0 \mathrm{~mm}$ of total length, $25 \mathrm{~mm}$ correspond to the crown) and shows characters common to most of the other teeth: the crown is provided with two mesiodistal carinae, which are not serrated; the base of the crown is slightly elliptical (17.0 mm long and $15.3 \mathrm{~mm}$ wide in MGUV 16006); and there is no constriction between the crown and the root. MGUV 14436 is an exception because it has a modest constriction at the base of the crown. On some teeth, the surface has several longitudinal ridges (about 10 on the lingual surface of MGUV 14436). Both shed teeth, with a totally reabsorbed root (MGUV 14443, 16004: Fig. 3.9, 3.10), and teeth still preserving the root (MGUV 16006) are present.

Three isolated vertebrae (MGUV 14463, 14464, and 14465) are represented by an incomplete, procoelous centrum, whose estimated original length was about $25-30 \mathrm{~mm}$ 

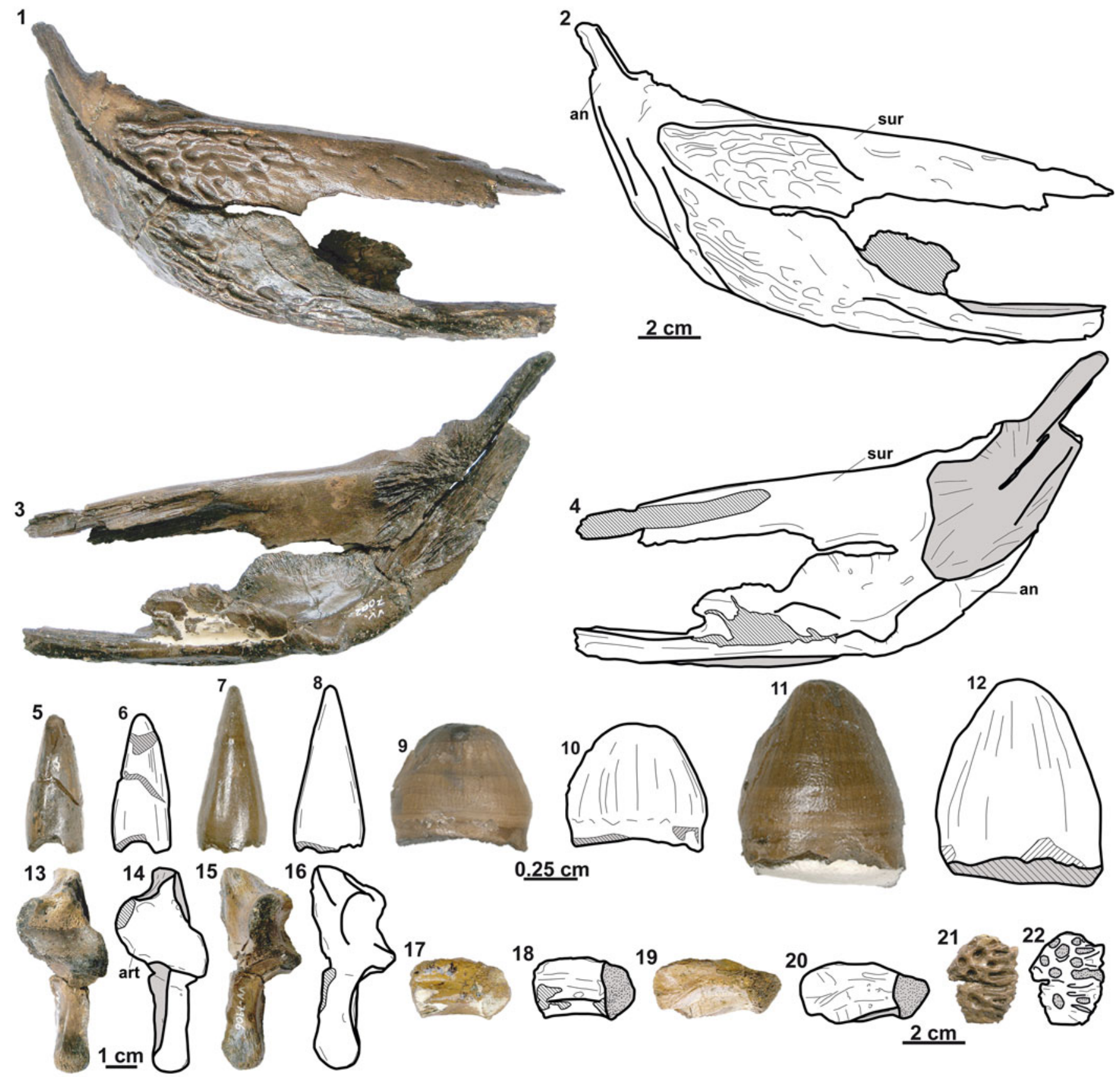

Figure 3. Photos and line drawings of crocodylian remains from the late Miocene of Venta del Moro. (1-4) Right surangular (MGUV 18835) joined with the corresponding angular MGUV 14466: (1, 2) lateral view; (3,4) medial view. (5-12) Isolated teeth (MGUV 16002, 16001, 16004, 14504) in labial views. (13-16) Right articular (MGUV 14475): $(\mathbf{1 3}, \mathbf{1 4})$ dorsal view; $(\mathbf{1 5}, \mathbf{1 6})$ medial view. (17-20) Centra of isolated vertebrae (MGUV 14464-5) in left lateral views. (21, 22) Fragmentary osteoderm (MGUV 14471) in external view. an = angular; art = articular; sur = surangular. Oblique lines denote missing portions or cast.

(Fig. 3.17-3.20). The centra were separated from the neural arch at the level of the neurocentral synchondrosis in at least MGUV 14464 and 14465. A well-developed hypapophysis is present in MGUV 14463; MGUV 14465 does not show any hypapophysis, and its ventral surface is wide and flat (the other centrum is ventrally eroded, but probably the hypapophysis was not present; Fig. 3.17, 3.18).

The only clearly identifiable but fragmentary osteoderm is MGUV 14471. It is characterized by very deep and relatively large, elongated pits separated by rounded ridges (Fig. 3.21, 3.22). Only two original edges are preserved: one is smooth and straight and thins gradually; the other is thick and hosts a well-developed suture. The entire osteoderm was probably rather large, the preserved portion being $31 \mathrm{~mm}$ long and $25 \mathrm{~mm}$ wide (Fig. 3.21). MGUV 14474 is a possible second, very fragmentary, osteoderm.

Materials.-MGUV 14469: right jugal; MGUV 14472: frontal; MGUV 14467: right quadrate; MGUV 18828: right squamosal, 
exoccipital, and quadrate; MGUV 14470: fragmentary parietal and supraoccipital; MGUV 14816: ectopterygoid; MGUV 18835: right surangular; MGUV 14466: right angular; MGUV 14475: right articular; MGUV 14436-62, 14468, 14490, 14502, 14607, 15853, 16001-16006, 18932, 24317, $25923-$ 25926, 25993: isolated teeth; MGUV 14463-14465: isolated vertebrae; MGUV 14471: osteoderm; MGUV 14473: unidentified fragment of skull bone; MGUV 14474: fragmentary osteoderm.

Remarks. - The crocodylian remains from VM, despite being very fragmentary, show characters that clearly allow us to exclude their referral to either Diplocynodon or tomistomines-the only crocodylians besides Crocodylus known to have inhabited the Mediterranean Basin during the late Neogene. The described remains do not belong to Diplocynodon because the latter, as all alligatoroids, is characterized by a dorsal opening of the foramen aëreum, whereas both MGUV 14467 and MGUV 18828, despite not showing the original position of the foramen, clearly indicate that it was placed close to the dorsomedial edge of the quadrate. Moreover, the quadrate medial hemicondyle of MGUV 18828 is clearly dorsally expanded, instead of sloping with a notch corresponding to the foramen aëreum as in Diplocynodon. In addition, the frontal MGUV 14472 does not show the step at the base of the frontal process that characterizes, among others, Diplocynodon, and at the same time, it shows a deeply concave frontoparietal suture instead of being rectilinear (or nearly so) as in tomistomines (see character 151 in Brochu and Storrs, 2012). Even if highly fragmentary, the preserved morphology of the osteoderm MGUV 14471 does not fit with either that of tomistomines (characterized by relatively few and comparatively very large pits; see Zoboli et al., 2019, fig. 8) or that of Diplocynodon (e.g., see Delfino and Smith, 2012; Martin et al., 2014). Moreover, the development of the lamina of the articular lying against the surangular (among others, see Brochu and Storrs, 2012) also allows us to rule out the extant African crocodylid Mecistops, which was never recovered in the North African and European fossil record. The morphology of the crocodylian remains from VM is congruent with that of Crocodylus, although it is not possible to detect any of the apomorphies of this genus (Brochu, 2000) among the currently available material. Consequently the morphology of the remains from VM does not permit us to confirm their referral to C. checchiai, a species originally described by Maccagno (1947, 1952) on the basis of well-preserved skulls from the latest Miocene locality of As Sahabi (Libya). Further remains of $C$. checchiai from As Sahabi were later described by Delfino (2008), but it is thanks to the new material from the Turkana Basin (Kenya) recently described by Brochu and Storrs (2012) that the phylogenetic relationships of this taxon have been further clarified, confirming its referral to Crocodylus. New evidence (Delfino et al., 2020) based on the revision of material originally described by Maccagno strengthens the referral of C. checchiai to Crocodylus by placing it at the base of the American extinct and extant species and, supporting and African American dispersal, testify for the dispersal abilities of the late Miocene crocodylids that inhabited the Mediterranean area. Other late Miocene crocodylians from Northern Africa have not been described and identified in detail, but worth mentioning are the materials from Tizi N'Tadderht (Morocco; Zouhri et al., 2012) and Djebel Krechem el Artsouma (Tunisia; Geraads, 1989). The Moroccan locality yielded a skull referred to Crocodylus cf. C. niloticus Laurenti, 1768 whereas the Tunisian material has been referred to Crocodylus $\mathrm{cf}$. C. checchiai but should be revised now that the morphology of the topotypic remains is better known than before (Delfino et al., 2020). The African $C$. checchiai is characterized by a set of features (among others, the mid-rostral boss) that are not accessible among the material from VM. Even if $C$. checchiai is so far the only well-known short-snouted crocodylid species that inhabited the Mediterranean Basin during the late Miocene, it does not seem advisable to refer the material from VM to this species on the basis of geography alone (especially considering that the former has only been unambiguously identified in Libya and Kenya so far). Thus, based on its preserved morphology, biogeography, and chronology, the VM crocodylian is here referred to cf. Crocodylus sp., an assignment that could be confirmed by the retrieval of additional and more-informative material.

\section{Discussion}

The geographic area of origin of the genus Crocodylus is currently unresolved by the fossil record and could be located in either Asia or Africa (Oaks, 2011; Brochu and Storrs, 2012). This lack of knowledge, besides the poor taxonomic resolution provided by the VM material, precludes a firm biogeographical interpretation of the VM crocodylian. According to Pickford and Morales (1994), MN13 is a phase of northward latitudinal shift of the boundary zone between tropical and boreal biogeographic realms. This shift could explain the presence of Crocodylus at Gargano and its possible presence at VM (both MN13) but does not explain its possible presence at Montebamboli (MN12) and, even less, Scontrone (MN11), which are older. Delfino and Rossi (2013) proposed that Crocodylus could have repeatedly dispersed from Africa to Europe across the Mediterranean Basin. As the latter was a small sea scattered with islands, especially during the late Neogene, it would not have represented an important biogeographic barrier to members of this genus, which is well known for being able to survive in saltwater (Leslie and Taplin, 2001) and includes at least some extant species that are able to quickly disperse across saltwater (Campbell et al., 2010). The fact that the paleo-Mediterranean Basin could be easily crossed is further corroborated by the slightly earlier (6.3 Ma) FAD of the hippopotamid Hexaprotodon in Spain, which is thought to have dispersed from Africa by swimming through the Rifian Corridor before the subsequent intercontinental faunal exchanges between Iberia and North Africa at 6.2 Ma (Gibert et al., 2013, and references therein). The evolution of endemic hippopotamus species in fossil islands has been classically explained by their purported good swimming abilities (e.g., Sondaar, 1977). Although this has recently been challenged (Mazza, 2014, 2015) on the grounds that Hippopotamus amphibius Linnaeus, 1758 adults are too dense to float on freshwater (Coughlin and Fish, 2009), this does not apply to juvenile individuals and, hence, must not necessarily be the case for extinct hippopotamid species, particularly on saltwater due to increased buoyancy (van der Geer et al., 2015). 
There is no geological evidence for the land bridges hypothesized by Mazza $(2014,2015)$ to explain the dispersal of hippopotami to islands such as Cyprus, Madagascar, and Crete (van der Geer et al., 2015). In the case of the Iberian Peninsula during the latest Miocene, the earlier dispersal of hippopotami as compared with terrestrial mammals argues in favor of dispersal through seawater, once the Betic Seaway was already closed and the Riftian corridor very restricted (Gibert et al., 2013). It is therefore interesting that material potentially referable to Crocodylus is recorded in the Iberian Peninsula because, so far, the evidence for the presence of this taxon in the northern Mediterranean area was limited to three localities in the Apennine Peninsula.

\section{Conclusions}

The crocodylian fossil remains from the late Miocene (6.23 Ma) of VM are too fragmentary to assess their previous assignment to C. checchiai but allow us to rule out an assigment to either Diplocynodon or tomistomines, the two other crocodylian clades previously recorded from the late Miocene of Europe. Therefore, a tentative assignment to cf. Crocodylus is warranted on morphological grounds. The identification of at least two individuals (as testified by the two right quadrates) indicates that the possible presence of Crocodylus at VM cannot be due to the occasional dispersal of just one individual but suggests that a population could have been present in the area. All the European localities with late Miocene crocodylians, VM included, were at that time close to the northern shores of the Mediterranean and therefore easily reachable by specimens dispersing via seawater. The fact that $C$. checchiai from Libya is phylogenetically intermediate between the African $C$. niloticus and the American Crocodylus, coupled with the fact that C. checchiai predates the appearance of this genus in America, supports good dispersal abilities of the late Miocene African crocodylids. Therefore, like the hippopotamid Hexaprotodon, the genus Crocodylus could have dispersed by seawater from Africa into Europe somewhat before the establishment of a clear land connection between these two continents. However, it is quite frustrating that, so far, all these late Miocene crocodylians from Europe are represented by isolated teeth, osteoderms, or highly fragmentary remains that hinder a precise specific identification and therefore the retrieval of precise information unveiling the biogeographic history of the last European crocodylians.

\section{Acknowledgments}

Fieldwork in Venta del Moro from 1995 to 2012 was supported by the Conselleria de Cultura of the Valencian Government and by the Conselleria d'Empresa, Universitat i Ciència of the Generalitat Valenciana (project number GV06/304), with the permission of the Ministerio de Fomento and the Company ADIF, of the Spanish Government. This research has been funded by the Ministerio de Ciencia e Innovación (PGC2018094122-B-100), the Agencia Estatal de Investigación (CGL201676431-P; AEI/FEDER, UE), the Research Groups CSIC 641538 and CAM-UCM 910607, and the Generalitat de Catalunya (CERCA Programme, consolidated research group 2017 SGR
116 GRC to D.M.A., and Beatriu de Pinós contract 2017 BP 00223 from AGAUR to J.A.). E.T. contributed to this project while funded by the European Union's FP7 program under the Marie Skłodowska-Curie grant agreement no. 609402 - 2020 researchers: Train to Move (T2M). À.H.L. is financially supported through a postdoctoral grant from Operational Programme Research, Development and Education-Project 'Postdoc@MUNI' (no. CZ.02.2.69/0.0/0.0/ 16_027/0008360). M.D. acknowledges also the University of Turin (Fondi di Ateneo 2018 and 2019). We further thank J. Martin for providing relevant literature. The latter, along with C.A. Brochu, reviewed the manuscript and provided useful suggestions.

\section{References}

Abbazzi, L., Delfino, M., Gallai, G., Trebini, L., and Rook, L., 2008, New data on the vertebrate assemblage of Fiume Santo (North-western Sardinia, Italy), and overview on the late Miocene Tusco-Sardinia paleobioprovince: Palaeontology, v. 51, p. 425-451.

Abella, J., Montoya, P., and Morales, J., 2014, Paleodiversity of the superfamily Ursoidea (Carnivora, Mammalia) in the Spanish Neogene, related to environmental changes: Journal of Iberian Geology, v. 40, p. 11-18.

Abella, J., Hontecillas, D., Valenciano, A., Montoya, P., Morales, J., Pesquero, M.D., and Alcalá, L., 2019, The last record of an ailuropod bear from the Iberian Peninsula, in Bonis, L. de., and Werdelin, L., eds., Memorial to Stéphane Peigné-Carnivores (Hyaenodonta and Carnivora) of the Cenozoic: Geodiversitas, v. 41, no. 23, p. 797-809.

Aguirre, E., Robles, F., Thaler, L., López Martínez, N., Alberdi, M.T., and Fuentes, C., 1973, Venta del Moro, nueva fauna finimiocena de moluscos y vertebrados: Estudios Geologicos, v. 29, 569-578.

Agustí, J., Garcés, M., and Krijgsman, W., 2006, Evidence for African-Iberian exchanges during the Messinian in the Spanish mammalian record: Palaeogeography, Palaeoclimatology, Palaeoecology, v. 238, p. 5-14.

Alba, D.M., Montoya, P., Pina, M., Rook, L., Abella, J., Morales, J., and Delson E., 2015, First record of Mesopithecus (Cercopithecidae, Colobinae) from the Miocene of the Iberian Peninsula: Journal of Human Evolution, v. 88, p. $1-14$.

Alfaro, P., Soria, J.M., and Ruiz Bustos, A., 1995, Precisiones biostratigraficas y paleoecologicas en el Neógeno de la cuenca del Bajo Segura (Cordillera Bética Oriental): Estudios Geológicos, v. 51, p. 57-63.

Blainville, H.M.D. de, 1855, Ostéographie. Atlas du Genre Crocodilus. Explication des planches: Paris, J.B. Bailliere et fils, 63 p.

Böhme, M., 2003, Miocene Climatic Optimum: evidence from lower vertebrates of central Europe: Palaeogeography, Palaeoclimatology, Palaeoecology, v. 195 , p. 389-401.

Böhme, M., and Ilg, A., 2003, fosFARbase: Database of vertebrates: www. wahre-staerke.com/ (accessed November 2015).

Brochu, C.A., 2000, Phylogenetic relationships and divergence timing of Crocodylus based on morphology and the fossil record: Copeia, v. 2000, p. $657-673$.

Brochu, C.A., 2007, Systematics and taxonomy of Eocene tomistomine crocodylians from Britain and Northern Europe: Journal of Paleontology, v. 50, p. $1-13$.

Brochu, C.A., and Storrs, G.W., 2012, A giant crocodile from the PlioPleistocene of Kenya, the phylogenetic relationships of Neogene African crocodylines, and the antiquity of Crocodylus in Africa: Journal of Vertebrate Paleontology, v. 32, p. 587-602.

Buckland, W., 1836, Geology and Mineralogy Considered with Reference to Natural Theology, Volume 2: London, Pickering, 128 p.

Campbell, H.A., Watts, M.E., Sullivan, S., Read, A.M., Choukroun, S., Irwin S.R., and Franklin, C.E., 2010, Estuarine crocodiles ride surface currents to facilitate long-distance travel: Journal of Animal Ecology, v. 79, p. $955-964$.

Casas-Gallego, M., Lassaletta, L., Barrón, E., Bruch, A.A., and Montoya, P., 2015, Vegetation and climate in the eastern Iberian Peninsula during the pre-evaporitic Messinian (late Miocene). Palynological data from the Upper Turolian of Venta del Moro (Spain): Review of Palaeobotany and Palynology, v. 215, p. 85-99.

Colombero, S., et al., 2017, Late Messinian mollusks and vertebrates from Moncucco Torinese, north-western Italy. Paleoecological and paleoclimatological implications: Palaeontologica Electronica, v. 20, 20.1.10A, doi: $10.26879 / 658$. 
Coughlin, B.L., and Fish, F.E., 2009, Hippopotamus underwater locomotion: reduced-gravity movements for a massive mammal: Journal of Mammalogy, v. 90 , p. 675-679.

Crespo, V.D., Sevilla, P., Mansino, S., Montoya, P., and Ruiz-Sánchez, F.J., 2018, Bats from the classical site of Venta del Moro (late Miocene, eastern Spain): Historical Biology, v. 30, p. 317-326.

Cuvier, G., 1807, Sur les différentes espèces de crocodiles vivans, et sur leurs caractères distinctifs: Annales du Muséum national d'histoire naturelle Paris, v. 10, p. 8-86.

De Bruijn, H., Daams, R., Daxner-Höck, G., Falhbusch, V., Ginsburg, L., Mein, P., and Morales, J., 1992, Report of the RCMNS working group on fossil mammals, Reisensburg 1990: Newsletters on Stratigraphy, v. 26, p. 65-118.

Delfino, M., 2002, Erpetofaune italiane del Neogene e del Quaternario [Ph.D. Dissertation]: Modena, Università degli Studi di Modena e Reggio Emilia, $382 \mathrm{p}$.

Delfino, M., 2008, New remains of Crocodylus checchiai Maccagno, 1947 (Crocodylia, Crocodylidae) from the late Miocene of As Sahabi, Libya, in Boaz, N.T., El-Arnauti, A., Pavlakis, P., Salem, M., eds., CircumMediterranean Geology and Biotic Evolution during the Neogene Period: The Perspective from Libya: Garyounis Science Bulletin special issue, v. 5, p. 111-118.

Delfino, M., and Rook, L., 2008, African crocodylians in the late Neogene of Europe. A revision of Crocodylus bambolii Ristori, 1890: Journal of Paleontology, v. 82, p. 336-343.

Delfino, M., and Rossi, M.A., 2013, Fossil crocodylid remains from Scontrone (Tortonian, Southern Italy) and the late Neogene Mediterranean biogeography of crocodylians: Geobios, v. 46, p. 25-31.

Delfino, M., and Smith, T., 2009, A reassessment of the morphology and taxonomic status of 'Crocodylus' depressifrons Blainville, 1855 (Crocodylia, Crocodyloidea) based on the early Eocene remains from Belgium: Zoological Journal of the Linnean Society, v. 156, p. 140-167.

Delfino, M., and Smith, T., 2012, Reappraisal of the morphology and phylogenetic relationships of the alligatoroid Diplocynodon deponiae (Frey, Laemmert and Riess, 1987), based on a three-dimensional specimen: Journal of Vertebrate Paleontology, v 32, p. 1358-1369.

Delfino, M., Böhme, M., and Rook, L., 2007, First European evidence for transcontinental dispersal of Crocodylus (late Neogene of southern Italy): Zoological Journal of the Linnean Society, v. 149, p. 293-307.

Delfino, M., Martin, J.E., de Lapparent de Broin, F., and Smith, T., 2019, Evidence for a pre-PETM dispersal of the earliest European crocodyloids: Historical Biology, v. 31, p. 845-852.

Delfino, M., Iurino, D., Mercurio, B., Piras, P., Rook, L., and Sardella, R., 2020, Old African fossils provide new evidence for the origin of the American crocodiles: Scientific Reports, v. 10, doi:10.1038/s41598-020-68482-5.

De Zigno, A., 1880, Sopra un cranio di coccodrillo scoperto nel terreno eoceno del Veronese. Atti della Accademia Nazionale dei Lincei. Classe di Scienze Fisiche, Matematiche e Naturali: Rendiconti Lincei. Serie IX. Matematica e Applicazioni, v. 5, p. 65-72.

Díaz Aráez, J.L., Delfino, M., Luján, À.H., Fortuny, J., Bernardini, F., and Alba, D.M., 2017, New remains of Diplocynodon (Crocodylia: Diplocynodontidae) from the early Miocene of the Iberian Peninsula: Comptes Rendus Palevol, v. 16, p. 12-26.

Freudenthal, M., 1971, Neogene vertebrates from the Gargano peninsula, Italy: Scripta Geologica, v. 3, p. 1-10.

García-Alix, A., Minwer-Barakat, R., Martín Suárez, E., Freudenthal, M., Aguirre, J., and Kaya, F., 2016, Updating the Europe-Africa small mammal exchange during the late Messinian: Journal of Biogeography, v. 43, p. $1336-1348$.

Georgalis, G.L., Villa, A., Vlachos, E., and Delfino, M., 2016, Fossil amphibians and reptiles from Plakias, Crete: a glimpse into the earliest late Miocene herpetofaunas of southeastern Europe: Geobios, v. 49, p. 433-444.

Geraads, D., 1989, Vertébrés fossiles du Miocène supérieur du Djebel Krechem el Artsouma (Tunisie Centrale). Comparaisons biostratigraphiques: Geobios, v. 5, p. 777-801

Gibert, L., Scott, G.R., Montoya, P., Ruiz-Sánchez, F., Morales, J., Luque, L., Abella, J., and Lería, M., 2013, Evidence for an African-Iberian mammal dispersal during the pre-evaporitic Messinian: Geology, v. 41, p. 691-694.

Gmelin, J., 1789, Linnei Systema Naturae: Leipzig, G.E. Beer.

Guerra-Merchán, A., Serrano, F., Ruiz Bustos, A., Garcés, M., Insua-Arévalo, J.M., and García-Aguilar, J.M., 2013, Approach to the lower Pliocene marine-continental correlation from southern Spain. The micrommamal site of Alhaurín el Grande-1 (Málaga Basin, Betic Cordillera, Spain): Estudios Geológicos, v. 69, p. 85-96.

Kotsakis, T., Delfino, M., and Piras, P., 2004, Italian Cenozoic crocodilians: taxa, timing and palaeobiogeographic implications: Palaeogeography, Palaeoclimatology, Palaeoecology, v. 210, p. 67-87.

Laurenti, J.N., 1768, Austriaci Viennensis Specimen Medicum, Exhibens Synopsin Reptilium Emendatam cum Experimentis circa Venena et Antidota Reptilium Austriacorum: Vienna, J.T. de Trattnern, 214 p.
Leslie, A.J., and Taplin, L.E., 2001, Recent development in osmoregulation of crocodilians, in Grigg, G.C., Seebacher, F., and Franklin, C.E., eds., Crocodilian Biology and Evolution: Chipping Norton, Surrey Betty \& Sons, p. 265-279.

Linnaeus, C., 1758, Systema Naturae per Regna Tria Naturae, Secumdum Classes, Ordines, Genera, Species, Cum Characteribus, Differentiis, Synonymis, Locis (tenth edition): Stockholm, Laurentii Salvii.

Luján, À.H., Chroust, M., Čerňanský, A., Fortuny, J., Mazuch, M., and Ivanov, M., 2019, First record of Diplocynodon ratelii Pomel, 1847 from the early Miocene site of Tušimice (Most Basin, Northwest Bohemia, Czech Republic): Comptes Rendus Palevol, v. 18, p. 877-889.

Maccagno, A.M., 1947, Descrizione di una nuova specie di "Crocodilus" del Giacimento di Sahabi (Sirtica): Atti della Accademia Nazionale dei Lincei: Memorie della Classe di Scienze Fisiche, Matematiche e Naturali, Serie 8, Sezione II, fisica, chimica, geologia, paleontologia e mineralogia, v. 1, p. 61-96.

Maccagno, A.M., 1952, I coccodrilli di Sahabi: Rendiconti Accademia Nazionale Quaranta, v. 3, p. 73-117.

Mansino, S., Ruiz-Sánchez, F.J., Freudenthal, M., and Montoya, P., 2014, A new approach to the late Miocene-early Pliocene forms of the genus Apocricetus. Apocricetus alberti (Rodentia, Mammalia) from Venta del Moro (Cabriel Basin, Spain): Proceedings of the Geologists' Association, v. 125 , p. $392-405$.

Mansino, S., García-Alix, A., Ruiz-Sánchez, F.J., and Montoya, P., 2015a, A new Eliomys from the late Miocene of Spain, and its implications for the phylogeny of the genus: Acta Palaeontolologica Polonica, v. 60, p. 577-588.

Mansino, S., Ruiz-Sánchez, F.J., de Luque, L., Montoya, P., Gibert, L., Morales, J., Abella, J., Crespo, V.D., and Scott, G.R., 2015b, First early Pliocene micromammal faunas from the Venta del Moro area (Cabriel Basin, Spain): new data on the Messinian dispersal of Debruijnimys: Journal of Iberian Geology, v. 41, p. 273-293.

Mansino, S., Crespo, V.D., Montoya, P., and Ruiz-Sánchez, F.J., 2017, Muridae from the late Miocene site of Venta del Moro (eastern Spain): Historical Biology, v. 29, p. 677-691.

Mansino, S., Ruiz-Sánchez, F.J., and Montoya, P., 2018, Sciuridae (Rodentia, Mammalia) from the late Miocene of Venta del Moro (Cabriel Basin, Spain): biostratigraphical, phylogenetic and palaeoecological inferences: Historical Biology, v. 30, p. 297-304.

Martin, J.E., and Buffetaut, E., 2008, Crocodilus affuvelensis Matheron, 1869 from the Late Cretaceous of southern France: a reassessment: Zoological Journal of the Linnean Society, v. 152, p. 567-580.

Martin, J.E., Smith, T., de Lapparent de Broin, F., Escuillié, F., and Delfino, M. 2014, Late Paleocene eusuchian remains from Mont de Berru, France and the origin of the alligatoroid Diplocynodon: Zoological Journal of the Linnean Society, v. 172, p. 867-891.

Matheron, P., 1869, Note sur les reptiles fossiles des depôts fluvio-lacustres crétacés du bassin à lignite de Fuveau: Bulletin de la Société géologique de France, v. 26, p. 781-795.

Mazza, P., 2014, If hippopotamuses cannot swim, how did they colonize islands?: Lethaia, v. 47, p. 494-499.

Mazza, P., 2015, To swim or not to swim, that is the question: a reply to van der Geer et al.: Lethaia, v. 48, p. 289-290.

Mein, P., 1990, Updating of MN zones, in Lindsay, E.H., Fahlbush, V., and Mein, P., eds., European Neogene Mammal Chronology: New York, Plenum Press, p. 73-90.

Mein, P., 1999, European Miocene mammal biochronology, in Rössner, G.E., and Heissing, K., eds., The Miocene Land Mammals of Europe: München, Verlag Dr. Friedrich Pfeil, p. 25-38.

Meredith, R.W., Hekkala, E.R., Amato, G., and Gatesy, J., 2011, A phylogenetic hypothesis for Crocodylus (Crocodylia) based on mitochondrial DNA: evidence for a trans-Atlantic voyage from Africa to the New World: Molecular Phylogenetics and Evolution, v. 60, p. 183-191.

Michaux, J., 1969, Muridae (Rodentia) du Pliocéne supérieur d'Espagne et du Midi de la France: Palaeovertebrata, v. 3, p. 1-25.

Minwer-Barakat, R., García-Alix, A., Agustí, J., Martín Suárez, E., and Freudenthal, M., 2009, The micromammal fauna from Negratín-1 (Guadix Basin, southern Spain): new evidence of African-Iberian mammal exchanges during the late Miocene: Journal of Paleontology, v. 83, p. 854-879.

Minwer-Barakat, R., Agustí, J., García-Alix, A., and Martín-Suárez, E., 2018, The European record of the gerbil Myocricetodon (Rodentia, Mammalia) and its bearing on the Messinian salinity crisis: Palaeogeography, Palaeoclimatology, Palaeoecology, v. 506, p. 168-182.

Montoya, P., 1994, Los macromamíferos del Mioceno superior del área de Crevillente (Alicante) [Ph.D. Dissertation]: València, Universitat de València, $421 \mathrm{p}$.

Montoya, P., and Alberdi, M.T., 1995, Crevillente 15 y Crevillente 16, dos nuevos yacimientos con macromamíferos en el Mioceno superior de Alicante: Estudios Geológicos, v. 51, p. 159-182. 
Montoya, P., Morales, J., Robles, F., Abella, J., Benavent, J.V., Marín, M.D., and Ruiz Sánchez, F.J., 2006, Las nuevas excavaciones (1995-2006) en el yacimiento del Mioceno final de Venta del Moro, Valencia: Estudios Geológicos, v. 62, p. 313-326.

Montoya, P., Morales, J., and Abella, J., 2009, Eucyon debonisi n. sp., a new Canidae (Mammalia, Carnivora) from the latest Miocene of Venta del Moro (Valencia, Spain): Geodiversitas, v. 31, p. 709-722.

Montoya, P., Morales, J., and Abella, J., 2011, Musteloidea (Carnivora, Mammalia) from the late Miocene of Venta del Moro (Valencia, Spain): Estudios Geológicos, v. 67, p. 193-206.

Mook, C.C., 1940, A new fossil crocodilian from Mongolia: American Museum Novitates, no. 1097 , p. 1-3.

Mook, C.C., 1955, Two new genera of Eocene crocodilians: American Museum Novitates, no. 1727 , p. $1-4$.

Morales, J., 1984, Venta del Moro: su macrofauna de mamíferos y biostratigrafía continental del Mioceno terminal mediterráneo [Ph.D. Dissertation]: Madrid, Universidad Complutense de Madrid, 340 p.

Morales, J., Soria, D., and Aguirre, E., 1980, Camélido finimioceno en Venta del Moro. Primera cita para Europa Occidental: Estudios Geológicos, v. 36, p. 139-142.

Morales, J., Peláez-Campomanes, P., Abella, J., Montoya, P., Gibert, L., Scott, G., Cantalapiedra, J.L., and Sanisidro, O., 2013, The Ventian mammal age (latest Miocene): present state: Spanish Journal of Palaeontology, v. 28 , p. $149-160$.

Müller, S., 1846, Ueber den Charakter der Thierwelt auf den Inseln des indischen Archipels, ein Beitrag zur zoologischen Geographie: Weigmann's Archiv für Naturgeschichte, v. 12, p. 109-128.

Nicolaï, M.P.J., and Matzke, N.J., 2019, Trait-based range expansion aided in the global radiation of Crocodylidae: Global Ecology and Biogeography, v. 28 , p. $1244-1258$

Oaks, J.R., 2011, A time-calibrated species tree of Crocodylia reveals a recent radiation of the true crocodiles: Evolution, v. 65, p. 3285-3297.

Pesquero, M.D., Alberdi, M.T., and Montoya, P., 2007, Hipparion (Equidae, Mammalia) from Venta del Moro (Valencia Province, Spain): Neues Jahrbuch für Geologie und Paläontologie Abhandlungen, v. 243, p. 273-297.

Pickford, M., and Morales, J., 1994, Biostratigraphy and palaeobiogeography of East Africa and the Iberian Peninsula: Palaeogeography, Palaeoclimatology, Palaeoecology, v. 112, p. 297-322.

Pickford, M., Morales, J., and Soria, D., 1993, First fossil camels from Europe: Nature, v. 365 , p. 701

Pickford, M., Morales, J., and Soria, D., 1995, Fossil camels from the upper Miocene of Europe: implications for Biogeography and faunal change: Geobios, v. 28, p. 641-650.

Piñero, P., et al., 2017, Early Pliocene continental vertebrate fauna at Puerto de la Cadena (SE Spain) and its bearing on the marine-continental correlation of the late Neogene of eastern Betics: Palaeogeography, Palaeoclimatology, Palaeoecology, v. 479, p. 102-114.
Piras, P., Delfino, M., Del Favero, L., and Kotsakis, T., 2007, Phylogenetic position of the crocodylian Megadontosuchus arduini (De Zigno, 1880) and tomistomine palaeobiogeography: Acta Palaeontolologica Polonica, v. 52, p. 315-328.

Pomel, A., 1847, Note sur les animaux fossiles découverts dans le département de l'Allier: Bulletin de la Société Géologique de France, v. 4, p. 378-385.

Ristori, G., 1890, Sopra i Resti di un Coccodrillo Scoperti nelle Ligniti Mioceniche di Montebamboli (Maremma Toscana): Firenze, Reale Istituto di Studi Superiori Pratici e di Perfezionamento, Le Monnier, 44 p.

Rustioni, M., Mazza, P., Azzaroli, A., Boscagli, G., Cozzini, F., Di Vito, E., Masseti, M., and Pisanò, A., 1992, Miocene vertebrate remains from Scontrone, National Park of Abruzzi, central Italy: Rendiconti Lincei. Scienze Fisiche e Naturali, v. 9, p. 227-237.

Salesa, M.J., Antón, M., Turner, A., Alcalá, L., Montoya, P., and Morales, J., 2010, Systematic revision of the late Miocene sabre-toothed felid Paramachaerodus in Spain: Palaeontology, v. 53, p. 1369-1391.

Sondaar, P.Y., 1977, Insularity and its effect on mammal evolution, in Hecht, M.K., Goody, P.C., and Hecht, B.M., eds., Major Patterns of Vertebrate Evolution: New York, Plenum Press, p. 671-707.

Toula, F., and Kail, J.A., 1885, Über einen Krokodil-Schädel aus den Tertiärablagerungen von Eggenburg in Niederösterreich: eine paläontologische Studie: Denkschriften der Kaiserlichen Akademie der Wissenschaften, Mathematisch-Naturwissenschaftliche Classe, v. 50, p. 299-355.

van Dam, J., Aziz, H.A., Álvarez-Sierra, M., Hilgen, F.K., van den Hoek Ostende, L.W., Lourens, L.J., Mein, P., van der Meulen, A.J., and PeláezCampomanes, P., 2006, Long-period astronomical forcing of mammal turnover: Nature, v. 443, p. 687-691.

van der Geer, A.A.E., Anastasakis, G., and Lyras, G.A., 2015, If hippopotamuses cannot swim, how did they colonize islands: a reply to Mazza: Lethaia, v. 48, p. 147-150.

van der Made, J., and Morales, J., 1999, Family Camelidae, in Rössner, G.E., and Heissig, K., eds., The Miocene Land Mammals of Europe: München, Verlag Dr. Friedrich Pfeil, p. 221-224.

van der Made, J., Montoya, P., and Morales, J., 2006, Late Miocene turnover in the Spanish mammal record in relation to palaeoclimate and the Messinian Salinity Crisis: Palaeogeography, Palaeoclimatology, Palaeoecology, v. 238 , p. $228-246$

Zoboli, D., Sanciu, L., Pillola, G.L., and Delfino, M., 2019, An overview of the crocodylian fossil record from Sardinia (Italy): Annales de Paléontologie, v. 105 , p. $123-137$.

Zouhri, S., Geraads, D., El Boughabi, S., and El Harfi, A., 2012. Discovery of an upper Miocene vertebrate fauna near Tizi N'Tadderht, Skoura, Ouarzazate Basin (Central High Atlas, Morocco): Comptes Rendus Palevol, v. 11, p. $455-461$.

Accepted: 1 July 2020 